University of Nebraska - Lincoln

DigitalCommons@University of Nebraska - Lincoln

2007

\title{
THE GENEVA BOOMERANG: THE MILITARY COMMISSIONS ACT OF 2006 AND U.S. COUNTERTERROR OPERATIONS
}

Jack M. Beard

University of Nebraska-Lincoln, jbeard2@unl.edu

Follow this and additional works at: https://digitalcommons.unl.edu/lawfacpub

Beard, Jack M., "THE GENEVA BOOMERANG: THE MILITARY COMMISSIONS ACT OF 2006 AND U.S. COUNTERTERROR OPERATIONS" (2007). College of Law, Faculty Publications. 157.

https://digitalcommons.unl.edu/lawfacpub/157

This Article is brought to you for free and open access by the Law, College of at DigitalCommons@University of Nebraska - Lincoln. It has been accepted for inclusion in College of Law, Faculty Publications by an authorized administrator of DigitalCommons@University of Nebraska - Lincoln. 


\title{
THE GENEVA BOOMERANG: THE MILITARY COMMISSIONS ACT OF 2006 AND U.S. COUNTERTERROR OPERATIONS
}

\author{
By Jack M. Beard*
}

Over five years have passed since President George W. Bush issued the much-criticized order making an obscure device, military commissions, the primary tool for the United States to bring accused Qaeda terrorists to justice. ${ }^{1}$ Some legal scholars suggested in the wake of the issuance of that order that military commissions were the only practicable method available to address many of the problems presented by the trial of accused terrorists in civilian U.S. courts. ${ }^{2}$ True or not, it is clear that the decision to approach the problem of terrorists primarily in terms of war rather than crime continues to have far-reaching legal consequences. Following the Supreme Court's decision in Hamdan v. Rumsfeld, ${ }^{3}$ which found that the military commissions designed by the Bush administration were inconsistent with the requirements of both the Uniform Code of Military Justice (U.C.M.J.) and the law of war as incorporated in that statute, the U.S. Congress attempted to fashion a compliant charter for these commissions through the Military Commissions Act of 2006 (MCA). ${ }^{4}$

The MCA raises a variety of domestic and international legal issues. This brief essay focuses on the Act's potentially negative impact on U.S. counterterror operations and personnel. Part I provides an overview of some of the ways the MCA contradicts the law of war. ${ }^{5}$ These include concerns, identified and analyzed below, that the MCA has provided enough leeway for U.S. military commissions to become regarded as "kangaroo courts" and perhaps be allowed to consider evidence obtained through the use of highly coercive interrogation practices. Other contradictions of the law of war derive from the redefinition by Congress of some Geneva Convention offenses and prohibitions to resemble domestic crimes, its addition of new ones and omission of others, its rejection of international sources of law, and its conflation of the rules applicable to international and noninternational conflicts.

A state may cause a negative or "boomerang" effect on its own interests by the actions it takes with respect to its obligations under the law of war. The possible negative effects on U.S. operations and personnel resulting from the flaws in the MCA can be analyzed as two different types

* Professorial Lecturer, University of California at Los Angeles; former Associare Depury General Counsel (International Affairs), U.S. Department of Defense. The views expressed herein are those of the author alone and do not reflect the views of the Department of Defense or the U.S. government.

${ }^{1}$ Military Order, Detention, Treatment, and Trial of Certain Non-Citizens in the War Against Terrorism, 66 Fed. Reg. 57,833 (Nov. 16, 2001).

${ }^{2}$ See, e.g., Ruth Wedgwood, Al Qaeda, Terrorism, and Military Commissions, 96 AJIL 328 (2002).

${ }^{3}$ Hamdan v. Rumsfeld, 126 S.Ct. 2749 (2006).

${ }^{4}$ Military Commissions Acr of 2006, Pub. L. No. 109-366, 120 Stat. 2600 (to be codified at 10 U.S.C. $\$ \$ 948$ $950 \mathrm{w}$ and other sections of titles 10,18,28, and 42) [hereinafter MCA].

${ }^{5}$ The term "law of war" is referenced throughout the MCA and was applied by the Supreme Court in Hamdan as it was incorporated in the U.C.M.J. It is commonly used interchangeably with "international law of armed conflict," "jus in bello," and "international humanitarian law." While "law of war" is not defined in the MCA, Department of Defense $(\mathrm{DoD})$ regulations define it as " $[\mathrm{t}]$ hat part of international law that regulates the conduct of armed hostilities" and further specify that the term "encompasses all international law for the conduct of hostilities binding on the United States or its individual citizens, including treaties and international agreements to which the United States is a party, and applicable customary international law." DoD Law of War Program, DoD Directive 2311.01E, sec. 3.1. (May 9, 2006), available at <http://www.dtic.mil/whs/direcrives/search.html>. 
of boomerangs. The first type, examined in part II, could be described as a legal boomerang. Certain provisions in the MCA could undermine the credible commitment of the United States to the Geneva Conventions, estop the United States in the future from taking legal positions necessary to protect its military interests, and serve as a dangerous legal paradigm for adversaries of the United States in future conflicts. The second type, examined in part III, could be described as a political boomerang. The MCA's contradiction of the law of war could diminish U.S. chances of obtaining essential foreign support for actions against terrorism, particularly those seeking foreign cooperation in criminal matters, the use of critical foreign facilities, and the exercise of key rights that require foreign state authorizations. To the extent that U.S. policy is perceived by the international community as inconsistent with the Geneva Conventions, the law of war, and other international legal obligations, the MCA risks having an adverse effect on expanding U.S. antiterror operations, which increasingly depend on the cooperation of foreign countries and are often subject to the laws of foreign jurisdictions.

\section{THE MCA's CONTRADICTION OF THE LAW OF WAR}

The chief sponsors of the MCA in the U.S. Senate expressed complete confidence in the Act's adherence to the Geneva Conventions, ${ }^{6}$ but that confidence was misplaced. In at least five ways, the MCA contradicts the Geneva Conventions and related law of war principles.

\section{Standards for the Trial and Treatment of Detainees}

The Supreme Court in Hamdan found that compliance with the law of war is a condition precedent under the U.C.M.J. for the establishment of military commissions and that the Geneva Conventions are indisputably part of the law of war. ${ }^{7}$ While the full protections of the Third Geneva Convention ${ }^{8}$ were not implicated, the Court found common Article $3^{9}$ to be applicable to the conflict with Al Qaeda because it was a "conflict not of an international character occurring in the territory of one of the High Contracting Parties." ${ }^{10}$ One minimal protection provided by common Article 3 that was applied by the Supreme Court concerned the prohibition on "the passing of sentences and the carrying out of executions without previous judgment pronounced by a regularly constituted court affording all the judicial guarantees which are recognized as indispensable by civilized peoples." " Noting that common Article 3 "obviously tolerates a great degree of flexibility in trying individuals captured during armed conflict," ${ }^{12}$ the Court nonetheless

\footnotetext{
${ }^{6}$ See Kate Zernike, Senate Approves Broad New Rules to Try Detainees, N.Y. TIMES, Sept. 29, 2006, at Al (quoting Senator John McCain as promising his colleagues that " $[t]$ he conventions are preserved intact" and Senator Lindsey Graham as declaring after the vote on the MCA that "America can be proud. Not only did she adhere to the Geneva Conventions, she went further than she had to, because we're better than the terrorists.").

${ }^{7}$ Hamdan, 126 S.Ct. at 2786.

${ }^{8}$ Convention Relative to the Treatment of Prisoners of War, Art. 84, Aug. 12, 1949, 6 UST 3316, 75 UNTS 135 (consented to by the United States Senate on July 6, 1955, with reservations) [hereinafter Third Geneva Convention].

${ }^{9}$ Id., Art. 3 (which is common to all four Geneva Conventions of 1949) [hereinafter common Article 3].

${ }^{10}$ Hamdan, 126 S.Ct. at 2795 (quoting common Article 3).

${ }^{11}$ Id. (quoting common Article 3, para. 1(d)).

${ }^{12}$ Hamdan, 126 S.Ct. at 2798.
} 
concluded that the article does impose requirements and that military commissions can be considered "regularly constituted courts" under U.S. law only if they display uniformity with regular court-martial practice or some "practical need" explains any deviations. ${ }^{13}$

The military commissions invalidated by the Court in Hamdan substantially deviated from regular court-martial practice and were thus found to have not been authorized by Congress through the U.C.M.J. ${ }^{14}$ The determined efforts of senior U.S. military legal personnel and some members ofCongress to make the rules governing military commissions in the MCA fairer and more responsive to the Hamdan decision did result in the addition or clarification of several important rights. The MCA nonetheless authorizes significant deviations from regular court-martial practice. ${ }^{15}$ In attempting to prescribe its own interpretation notwithstanding these deviations, Congress declared any military commission established under the MCA to be "a regularly constituted court, affording all the necessary 'judicial guarantees which are recognized as indispensable by civilized peoples' for purposes of common Article 3 of the Geneva Conventions." ${ }^{16}$ At the same time, another section of the MCA criminalizing violations of common Article 3 incongruously omits any reference to such regularly constituted courts and judicial guarantees. ${ }^{17}$

In spite of Congress's assertions regarding the MCA's compliance with international legal standards, the plurality in Hamdan perhaps foreshadowed the reaction of many European and other governments to the deviations authorized by the MCA by arguing that a regularly constituted court "must be understood to incorporate at least the barest of those trial protections that have been recognized by customary international law." ${ }^{18}$ Foreign countries, including allies that provide critical support to U.S. counterterror operations, are likely to view the new military commissions in the context of the widely recognized and fundamental judicial guarantees referenced in common Article 3 and may disagree that the MCA successfully provides the "barest" of these required trial protections.

Consider, for example, interrogation standards for detainees. The MCA does include a provision prohibiting the cruel, inhuman, or unusual treatment or punishment of all persons in the custody or under the physical control of the United States, regardless of their nationality or physical location. ${ }^{19}$ However, the MCA still leaves the door open for admissible evidence to be obtained through varying degrees of coercion prohibited by the Geneva Conventions and gives the president the discretion and power to approve some problematic interrogation methods based on his own interpretation of Geneva Convention obligations. ${ }^{20}$ Moreover, considerable evidence indicates that the

${ }^{13} I d$. at 2797.

${ }^{14}$ Id. at 2798.

${ }^{15}$ The MCA makes hearsay evidence admissible under various conditions; permits classified information (or substitutions or summaries in its place) to be used against the defendant while restricting the ability to challenge the sources, methods, or activities by which the government acquired the evidence; allows the defendant to be excluded from the proceedings under some circumstances; imposes some limits on the right of defendants to be represented by counsel of their choosing; and makes inapplicable prohibitions in the U.C.M.J. related to compulsory self-incrimination and requirements for a speedy trial. MCA, supra note 4, sec. 4 (to be codified as amended in scattered sections of 10 U.S.C.).

${ }^{16} 10$ U.S.C. $\$ 948$ b(f) (quoting common Article 3, supra note 9, para. 1(d)).

1718 U.S.C. $\$ 2441$ note; see infra text at note 42 .

${ }^{18}$ Hamdan, 126 S.Ct. at 2797.

${ }^{19}$ MCA sec. 6(c), 42 U.S.C. $\$ 2000$ dd-0.

${ }^{20}$ The MCA bars military commissions from considering testimony obtained through interrogation methods that amount to cruel, inhuman, or degrading treatment, but retroactively only to December 30,2005 , the date on 
executive branch takes an expansive view of permissible interrogation methods. ${ }^{21}$ The MCA also does not specifically address the admissibility of statements obtained through interrogation methods that may constitute lesser violations of the Geneva Conventions (such as those involving "outrages upon personal dignity, in particular humiliating and degrading treatment," prohibited by common Article 3). Even evidence secured by torture may be considered by the military commissions if it involves a statement obtained before December 30,2005, suggesting a fundamental shift with respect to law of war principles that had previously been viewed as imposing absolute limits or prohibitions. ${ }^{22}$

\section{Redefining Combatancy}

The process by which the Bush administration has attempted to fit the square peg of diverse Qaeda criminal acts exclusively into the round hole of offenses against the law of war has not been an easy one. Such difficulties have contributed to the complete failure of military commissions to try even a single case since they were authorized in 2001 . Unsurprisingly, therefore, supporters of military commissions have complained about the lack of a list of "off-the-shelf" war crimes to use against accused terrorists. ${ }^{23}$

As Congress struggled to rewrite and expand war crimes coverage through the MCA, it also sought to cast an ever-wider net to capture not just alleged terrorists but those who are thought to be giving support to terrorists. In doing so, it redefined a fundamental concept in the law of war and the Geneva Conventions by using the term "unlawful enemy combatant" to include not only a person who directly engaged in hostilities against the United States, but also one "who has purposefully and materially supported hostilities against the United States or its cobelligerents who is not a lawful enemy combatant." 24

While civil libertarians are concerned about what the term "material support" may encompass with respect to the activities of ordinary persons living in the United States, ${ }^{25}$ for many

which the Detainee Treatment Act of 2005 was signed into law. Detainee Treatment Act of 2005, Pub. L. No. 109$148, \$ 1003,119$ Stat. 2739,2739 (to be codified at 42 U.S.C. $\$ 2000$ dd); MCA sec. 3, 10 U.S.C. $\$ 948$ r(d). Statements obtained through coercive interrogation methods that fall short of cruel, inhuman, or degrading treatment are not barred. Section 6(a) of the MCA gives the president the power "to interpret the meaning and application of the Geneva Conventions and to promulgate higher standards and administrative regulations for violations of treaty obligations which are not grave breaches of the Geneva Conventions." 18 U.S.C. $\$ 2441$ note. This section also asserts that executive orders containing such interpretations are "authoritative."

${ }^{21}$ In a 2002 memorandum to the president, White House counsel Alberto R. Gonzales specifically attacked law of war restrictions on executive branch policies in this area by arguing that " $[t]$ he war against terrorism is a new kind of war. .. . This new paradigm renders obsolete Geneva's strict limitations on questioning of enemy prisoners." Scott Shane, Terror and Presidential Power: Bush Takes a Step Back, N.Y. TIMES, July 12, 2006, at A20; see also Sean D. Murphy, Contemporary Practice of the United States, 98 AJIL 820, 822 (2004). Subsequent criticism of harsh interrogation techniques, particularly those reportedly practiced by employees of the Central Intelligence Agency, has not ended policies that countenance aggressive methods of questioning. Although specific methods used by the CIA have not been identified, President Bush stated that his "one test" for the MCA when it came to his desk was "whether it would allow the CIA Program to continue-and this bill meets that test." See White House, Fact Sheet: The Military Commissions Act of 2006 (Oct. 17, 2006), available at <http:/www.whitehouse.gov/news/releases/2006/10/20061017.html>.

22 W. Michael Reisman, Holding the Center of the Law of Armed Conflict, 100 AJIL 852, 853-54 (2006).

${ }^{23}$ JOHN YOO, WAR BY OTHER MEANS 208 (2006) (also conceding that, for various reasons, "[m] ilitary commissions have been the Bush administration's most conspicuous policy failure in the war against al Qaeda").

${ }^{24} 10$ U.S.C. $\$ 948 \mathrm{a}(1)$ (a)(i). This definition of combatancy removes any requirements for proximity to the battlefield itself and includes individuals supporting hostile actions against any "co-belligerent" country, not just the United States.

${ }^{25}$ Even though U.S. citizens may qualify as unlawful combatants, only alien unlawful combatants are subject to trial by military commissions under the MCA. 10 U.S.C. $\$ 948$ b(a). 
the term may be even more unsettling in the context of the law of war because of the way it dramatically expands the scope of combatancy. The distinction between combatants and civilians is a cardinal principle of the law of war, serving to ensure that armed conflicts are waged solely between and against combatants and not against the civilian population. ${ }^{26}$

The limited protections of common Article 3, however, apply only to "[p]ersons taking no active part in the hostilities." 27 Thus, while civilians enjoy general immunity from direct attacks, they can lose this protection during any period in which they take an "active" or "direct" part in hostilities. ${ }^{28}$ Determining precisely when noncombatants lose their protected status and become combatants as a result of their active or direct part in hostilities has not always been easy, ${ }^{29}$ but the distinction remains a bedrock principle of the law of war that also serves larger humanitarian and international legal purposes. ${ }^{30}$ The "material support" provision of the MCA melts this distinction.

\section{Adding Some New Offenses to the Law of War}

Another aspect of the MCA that contradicts the law of war is the addition of new war crimes, largely borrowed from domestic criminal law. Because unlawful combatants are exposed to penal sanctions in the domestic legal system, in many cases the Bush administration could have charged suspected Qaeda terrorists with ordinary criminal offenses before U.S. courts. While various perceived disadvantages led to a rejection of this course of action in favor of military commissions, the Court in Hamdan made it clear that the authority to establish military commissions is conditioned under U.S. law on compliance with the law of war. ${ }^{31}$

In crafting the MCA to respond to the Hamdan decision, Congress appears to have continued the administration's effort to have its cake and eat it, too, by taking advantage of the benefits afforded by military commissions yet authorizing those commissions to try alien unlawful combatants for crimes that resemble ordinary domestic offenses more than war crimes. One such crime that was inserted in the MCA is conspiracy, ${ }^{32}$ even though four Justices

\footnotetext{
${ }^{26}$ Legality of the Threat or Use of Nuclear Weapons, Advisory Opinion, 1996 ICJ REP. 226, 257 (July 8); Reisman, supra note 22, at 856 ("At the very heart of the law of armed conflict is the effort to protect noncombatants by insisting on maintaining the distinction between them and combatants.") Former secretary of defense Donald H. Rumsfeld ironically emphasized this point (in criticizing the Taliban's lack of insignia) by saying, "A central purpose of the Geneva Convention was to protect innocent civilians by distinguishing very clearly between combatants and noncombatants." Jim Garamone, Rumsfeld Explains Detainee Status, U.S. Dep't of Defense News (Feb. 8, 2002), available at <http://www.defenselink.mil/news/Feb2002/n02082002_200202086.html>.

${ }^{27}$ Common Article 3, supra note 9, para. 1.

${ }^{28}$ YORAM DINSTEIN, THE CONDUCT OF HOSTILITIES UNDER THE LAW OF INTERNATIONAL CONFLICT 27 (2004).

${ }^{29}$ Id. at $27-28$.

${ }^{30}$ INTERNATIONAL COMMITTEE OF THE RED CROSS, BASIC RULES OF THE GENEVA CONVENTIONS AND THEIR ADDITIONAL PROTOCOLS 7 (1983) (noting that respect for the lives and physical and moral integrity of those "who do not take a direct part in hostilities" is one of the "basic rules of international humanitarian law in armed conflicts"); William H. Taft IV, The Law of Armed Conflict After 9/1 1: Some Salient Features, 28 YALE J. INT'L L. 319, 323 (2003) ("Application of the law of armed conflict, and in particular its bedrock principles of distinction and fundamental protections, serves humanitarian ends and ultimately reinforces the rules governing international behavior at all times, even in war.").
}

${ }^{31}$ Hamdan v. Rumsfeld, 126 S.Ct. 2749, 2794 (2006).

3210 U.S.C. $\$ 950 \mathrm{v}(\mathrm{b})(28)$. 
in Hamdan strongly objected to the characterization of conspiracy as an independent war crime. ${ }^{33}$ On the basis of its unprecedented expansion of the definition of "combatancy," the MCA also lists "providing material support for terrorism" as a war crime, apparently reflecting a desire by Congress to establish a legal mechanism for imposing criminal penalties on individuals who support organizations engaged in terrorism. ${ }^{34}$ While prosecutors in U.S. courts may be able to pursue perjury, obstruction of justice, conspiracy, racketeering, or other charges to address various patterns of illegal activity that are carried out in furtherance of larger criminal enterprises, such ordinary domestic criminal offenses are not easily incorporated into the law of war. ${ }^{35}$

For example, even a common criminal offense such as murder, for which an unlawful combatant may be tried under ordinary domestic law, may be difficult to characterize as a war crime in the context of an attack on military personnel because combatants who are engaged in hostilities are not generally protected from attack under the law of war. Thus, absent some other violation, a war crime based solely on the killing of a combatant who is engaged in hostilities is problematic under the Geneva Conventions. ${ }^{36}$

Even if one accepts that the law of war may be understood by U.S. courts to be an "American common law of war" 37 that can be supplemented or even modified to some extent by U.S. laws, the hybrid version in the MCA fundamentally undermines the integrity of that body of law by importing into it ordinary domestic crimes that have no basis as war crimes. Moreover, it is likely also to raise concerns with respect to the ex post facto application of these new war crimes. Congress appears to have been concerned about such problems, as it included a statement of purpose in the MCA asserting that its provisions "codify offenses that have traditionally been triable by military commissions" and that the MCA does "not establish new crimes that did not exist before its enactment, but rather codifies those crimes for trial by military commission." 38

${ }^{33}$ Hamdan, 126 S.Ct. at 2785 ("Far from making the requisite substantial showing, the Government has failed even to offer a 'merely colorable' case for inclusion of conspiracy among those offenses cognizable by law-of-war military commission."). Other offenses that the MCA authorizes military commissions to try, such as perjury, false testimony, and obstruction of justice, would presumably raise similar concerns as independent war crimes if prosecutors are able to proceed on these secondary offenses in lieu of more widely recognized war crimes. The relevant section of the MCA appears, however, to impose limits in this regard by referring to "perjury, false testimony, or obstruction of justice related to military commissions under this chapter." 10 U.S.C. $\$ 950 \mathrm{w}(\mathrm{a})$ (emphasis added).

${ }^{34} 10$ U.S.C. $\$ 950 \mathrm{v}(\mathrm{b})(25)(\mathrm{A})$ provides:

Any person subject to this chapter who provides material support or resources, knowing or intending that they are to be used in preparation for, or in carrying out, an act of terrorism ...., or who intentionally provides material support or resources to an international terrorist organization engaged in hostilities against the United States, knowing that such organization has engaged or engages in terrorism . . . , shall be punished as a military commission under this chapter may direct.

${ }^{35}$ Perjury, for example, is an ordinary criminal offense that in some cases may not be available in the broader context of the law of war since combatants accorded prisoner-of-war (POW) status have only limited obligations to answer their interrogators' questions. See infra note 74.

${ }^{36}$ The drafters of the MCA appear to have struggled with this question when they established criminal penalties for an unlawful combatant "who intentionally kills one or more persons, including lawful combatants, in violation of the law of war." 10 U.S.C. $\$ 950 \mathrm{v}(\mathrm{b})(15)$. Since other provisions in the MCA specify offenses for the killing of noncombatants, it is unclear whether this section is intended to criminalize the killing of combatants absent some other "violation of the law of war."

${ }^{37}$ Hamdan, 126 S.Ct. at 2786.

${ }^{38} 10$ U.S.C. $\$ 950 \mathrm{p}(\mathrm{a})$. Since the provisions of the MCA are judged by Congress to be "declarative of existing law," Congress concludes that "they do not preclude trial for crimes that occurred before the date of [their] enactment." Id. $\$ 950 \mathrm{p}(\mathrm{b})$. 


\section{Omitting "Vague" Obligations and Rejecting "Non-U.S. Sources of Law"}

Presumably in an attempt to respond to the Supreme Court's decision in Hamdan to apply common Article 3 to the conflict with Al Qaeda, Congress included provisions in the MCA that amend the U.S. War Crimes $\mathrm{Act}^{39}$ to prohibit violations of common Article 3. Those provisions do so, however, in a manner that appears both confused and incomplete. First, the Act now prohibits violations only for crimes that constitute "grave breaches" of common Article 3, even though it has usually been assumed that the grave breaches regime applies only to armed conflicts of an international character. ${ }^{40}$ Second, it conspicuously omits two key prohibitions found in common Article 3. ${ }^{41}$ The first of these omissions is the prohibition against the passing of sentences and the carrying out of executions without previous judgment pronounced by a "regularly constituted court,"42 apparently a reflection of Congress's previously described doubts in the MCA about which rights are included among those judicial guarantees that are "recognized as indispensable by civilized peoples." The second omission is the prohibition against "[o]utrages upon personal dignity, in particular humiliating and degrading treatment." Although no explanation is provided in the MCA for this latter omission, the legal adviser of the Department of State referred to the wording of the prohibition as "vague." ${ }^{43}$ While vagueness undoubtedly can raise concerns in the field of criminal law and in some other areas of international law, such concerns have not prevented "outrages upon personal dignity" from being applied as a criminal offense by various international criminal tribunals. ${ }^{44}$

${ }^{39}$ MCA sec. 6(b), 18 U.S.C. $\$ 2441$ note.

${ }^{40} \mathrm{Id}$., sec. 6(a)(2). This section asserts that the Act's enumerated violations of common Article 3 "fully satisfy the obligation under Article 129 of the Third Geneva Convention for the United States to provide effective penal sanctions for grave breaches which are encompassed in common Article 3." Article 129 of the Third Geneva Convention, supra note 8, provides in pertinent part that " $[\mathrm{t}]$ he High Contracting Parties undertake to enact any legislation necessary to provide effective penal sanctions for persons committing, or ordering to be committed, any of the grave breaches of the present Convention defined in the following Article." The "following article," Article 130 of the Third Geneva Convention, makes no mention of common Article 3 and thus appears to be difficult to reconcile with the references to "grave breaches" in section 6(a)(2) of the MCA.

Some legal scholars view the regimes governing international and noninternational conflicts as increasingly converging and have observed that "[t] here is no moral justification, and no truly persuasive legal reason, for treating perpetrators of atrocities in internal conflicts more leniently than those engaged in international wars." See, e.g., Theodor Meron, Reflections on the Prosecution of War Crimes by International Tribunals, 100 AJIL 551, 573 (2006). As noted by Michael Matheson in his contribution to this Agora, the United States argued in 1995 in an amicus brief to the International Criminal Tribunal for the Former Yugoslavia in the case of Prosecutor $v$. Tadic that the "grave breaches" regime should be applied to internal as well as international conflicts. Michael J. Matheson, The Amendment of the War Crimes Act, 101 AJIL 48, 52-53 n.23 (2007).

${ }^{41}$ Section 6(b)(5) of the MCA does provide that "[r] he definitions in this subsection are intended only to define the grave breaches of common Article 3 and not the full scope of United States obligations under that Article." 18 U.S.C. $\$ 2441$ note. This provision could be interpreted as an acknowledgment that the United States remains obligated to observe all the prohibitions found in common Article 3, even though some are omitted with respect to the imposition of criminal sanctions. The MCA does not, however, elaborate on what constitutes the "full scope of U.S. obligations" and whether it includes the omitted provisions, making the U.S. commitment to full compliance with those obligations unclear.

42 The willingness of the plurality in Hamdan to use provisions of the International Covenant on Civil and Political Rights to illustrate the basic legal protections that are found in a "regularly constituted court affording all the judicial guarantees which are recognized as indispensable by civilized peoples" draws attention to the likely range of international debate over the import of this aspect of common Article 3. Hamdan, 126 S.Ct. at 2796-97 n.66.

${ }^{43}$ Vince Crawley, U.S. Dep't of State, International Information Programs, U.S. Official Explains New Military Commission Law: State's Bellinger Says Accused Will Receive Full and Fair Trials, Oct. 23, 2006, available at <http:// usinfo.state.gov/dhr/human_rights/detainees.html>.

${ }^{44}$ For example, the Statute of the International Criminal Court criminalizes "serious violations of article 3 common to the four Geneva Conventions of 12 August 1949" including "[c]ommitting outrages upon personal dignity, 


\section{Conflating the Laws Governing International and Noninternational Armed Conflicts}

The Geneva Conventions fail to explain precisely what constitutes a "conflict not of an international character" and no definition of that term enjoys universal acceptance other than statements contrasting it with its opposite. ${ }^{45}$ As a result, it was not a foregone conclusion that the U.S. Supreme Court in Hamdan would ultimately decide that Qaeda terrorists are engaged in an armed conflict governed by common Article 3. The Bush administration, however, argued that Hamdan was not entitled to any protections associated with a conflict of an international character, nor was he involved in a noninternational conflict to which common Article 3 applied. ${ }^{46}$ Confronted essentially with an argument by the executive that no protections under the law of war applied to its treatment of detainees, the Court found that at least the minimal protections of one provision of the Geneva Conventions, common Article 3, did apply.

As described above, Congress took a guarded approach in the MCA to extending protections under common Arricle 3 to unlawful combatants with a view to complying with the Supreme Court's decision in Hamdan. When it came to listing offenses triable by military commissions, however, Congress took an expansive approach and went beyond the relatively narrow set of violations usually associated with common Article 3. It did so by listing as triable offenses several crimes that are generally understood to be violations of the law of international armed conflict ${ }^{47}$ even though the Bush administration had argued in Hamdan that the conflict with $\mathrm{Al}$ Qaeda was not an international armed conflict to which the full protections of the Geneva Conventions apply. ${ }^{48}$ In spite of that distinction, the MCA essentially conflates many of the

in particular humiliating and degrading treatment." Rome Statute of the International Criminal Court, Art. 8(2)(c)(ii), July 17, 1998, 2187 UNTS 90; see also Prosecuror v. Aleksovski, No. IT-95-14/1-T (June 25, 1999) (finding Zlatko Aleksovski guilty of committing outrages against human dignity in violation of the Geneva Conventions); Prosecutor v. Kamuhanda, No. ICTR-95-54A-T (Jan. 22, 2004) (finding Jean de Dieu Kamuhanda guilty of commitring outrages against human dignity, among other crimes).

${ }^{45}$ LINDSAY MOIR, THE LAW OF INTERNAL ARMED CONFLICT 32 (2002).

${ }^{46}$ The government had asserted that common Article 3 did not apply to Hamdan because the conflict with Al Qaeda was "international in scope" "and thus did not qualify as a "conflict not of an international character." Hamdan, 126 S.Ct. at 2795. Previously, the Justice Department had argued in a memorandum to the president in 2002 that common Article 3 "refers specifically to a condition of civil war, or a large-scale armed conflict between a State and an armed movement within its own territory." Murphy, supra note 21 , at 821 . Since the beginning of Operation Enduring Freedom, the U.S. government has used several different legal rationales to explain why Qaeda detainees are not eligible for the full protections of the Third Geneva Convention and why the conflict with Al Qaeda is also beyond the reach of the Third Geneva Convention generally, including the argument that it is not applicable to a nonstate, terrorist group. Id. at 820-24; see also Sean D. Murphy, Contemporary Practice of the United States, 96 AJIL 461, 476-78 (2002).

${ }_{47}^{4}$ Much of the conduct criminalized in section 3 of the MCA goes beyond the limited rules that have traditionally been applied to noninternational armed conflicts. Enumerated war crimes that are more closely associated with international armed conflicts than common Article 3 violations include attacking protected property, pillaging, denying quarter, employing poison or similar weapons, using treachery or perfidy, and improperly using a flag of truce. While the United States cannot prosecute new crimes on the basis of conduct that occurred before the enactment of the MCA, Congress remains free to interpret common Article 3(1)(a) as now encompassing a larger set of violations of the law of war, including Hague Regulations such as those prohibiting the employment of poison or similar weapons, and to make these rules applicable to noninternational armed conflicts.

Even though some view the two regimes as increasingly converging, the distinction between rules governing international and those governing noninternational armed conflicts remains. That distinction, however, is further confused by the previously noted decision of Congress in the MCA to criminalize the most serious violations of common Article 3 by describing them as "grave breaches" when that term is widely recognized only in the context of international armed conflicts. See supra note 40 and corresponding text.

${ }^{48}$ Hamdan, 126 S.Ct. at 2794-95. 
rules governing international and noninternational conflicts, making violations under both regimes applicable to suspected Qaeda terrorists.

\section{LEGAL BOOMERANGS}

Images depicting the mistreatment of Iraqi detainees by U.S. personnel at the Abu Ghraib prison prompted calls in the U.S. Congress for the enactment of clearer and more humane standards to govern the detention and interrogation of persons in U.S. custody. ${ }^{49}$ While many commentators suggested that these graphic images of detainee abuse would lead to the mistreatment of captured U.S. personnel, some legal scholars have argued that the logic behind such claims is dubious. ${ }^{50}$ In examining states' compliance with obligations under the law of war, these scholars question implicit assumptions about the conditions of symmetry and reciprocity that make such obligations genuinely self-enforcing, and enable and motivate states to keep conflicts limited. ${ }^{51}$

Whether or not individual violations of the law of war by a state in a particular conflict produce immediate and traceable reciprocal action by other states, an act of Congress that officially attempts to reinterpret or revise key obligations under the Geneva Conventions and the law of war presents more complex and overarching law-related problems.

As a powerful state with worldwide military interests, the United States has had strong incentives to participate in formulating, supporting, and strengthening the Geneva Conventions and the law of war. Beyond promoting the rule of law, encouraging the proper treatment of captured U.S personnel, and serving larger humanitarian purposes, the observance of obligations under the law of war is viewed by the U.S. military as fundamentally advancing U.S. military objectives. ${ }^{52}$ For these reasons, the United States has generally resisted taking official actions with respect to law of war obligations and rights that would undermine the long-term American interests in maintaining the existing law of war regime.

It is thus not surprising that the Bush administration has already been forced to withdraw some "aggressive" interpretations of Geneva Convention obligations in light of their potential long-term negative impact on U.S operations. For example, President Bush decided on January 18, 2002, that the Geneva Conventions were inapplicable to Afghanistan's Taliban regime

\footnotetext{
${ }^{49}$ Congressional efforts to impose some standards on U.S. interrogation practices and the treatment of detainees included legislation introduced in October 2005, by Senator John McCain. A revised version of his proposal was later signed into law as part of the Detainee Treatment Act of 2005, supra note 20.

${ }^{50}$ See, e.g., Eric A. Posner, Terrorism and the Laws of War, 5 CHI. J. INT'L L. 423, 430 (2005) ("Suppose that the US's next war is with North Korea. There is no reason to believe that North Korea will torture American POWs because US forces tortured Iraqis."). Other aspects of reciprocity are also not guaranteed, as humane treatment of POWs by the United States in the North Korean and Vietnam conflicts did not prevent the systematic mistreatment of American POWs by those countries.

${ }^{51} I d$.

${ }^{52}$ Even if other countries make different calculations, the U.S. military incorporates the law of war into its training, plans, and operations on the basis of several assumptions. These include the positive role that the law of war can play in helping U.S. commanders to maintain discipline and efficiently employ U.S. forces and the negative effect that violations of the law of war may have in detracting from mission accomplishment and possibly leading to a loss of public support and/or an increase in enemy resistance. See W. Hays Parks, Teaching the Law of War, ARMY LAW., June 1987, at 4,5. Without making any distinctions as to conflicts or adversaries, official DoD policy thus provides that "[m]embers of the DoD Components comply with the law of war during all armed conflicts, however such conflicts are characterized, and in all other military operations." DoD Directive 2311.01E, supra note 5 , sec. 4.1 .
} 
largely on the basis of memorandums from the Department of Justice arguing that it was a "failed state" or nothing more than a militant group of terrorists. ${ }^{53}$ While accepting the Department of Justice's conclusion that he had the authority "to suspend [the Third Geneva Convention] as between the United States and Afghanistan," the president ultimately declined to exercise that authority and determined that the Geneva Conventions did apply to the conflict with the Taliban. ${ }^{54}$ This reevaluation of the complete inapplicability of the Geneva Conventions took place in the context of memorandums to the president from the Department of State emphasizing the negative impact of such an action on long-term U.S. interests. ${ }^{55}$ While captured Taliban fighters could properly be determined not to have fulfilled the four prerequisites of lawful belligerency and thus not to have qualified as prisoners of war (POWs), ${ }^{56}$ the issuance of sweeping pronouncements about the inapplicability of the Geneva Conventions to foreign countries by attaching labels to those countries would undermine the overall U.S. commitment to the Conventions and serve as a dangerous precedent in future conflicts. Such actions also make little sense for the U.S. government, as it has often taken a broad view of the different types of conflicts and enemies that can give rise to demands that captured U.S. soldiers be accorded POW status. ${ }^{57}$

At a fundamental level, unilateral revision of the Geneva Conventions by the United States undermines the credibility of the U.S. commitment to the existing Geneva regime. In an international setting that lacks effective external enforcement mechanisms, allowing the easy violation of agreements, a state may seek to send a signal of credible commitment to other states by constraining its own ability to act in ex ante legal structures, institutions, or procedures that reduce ex post incentives for such noncompliance. ${ }^{58} \mathrm{~A}$ legislative act that restrains or makes it

${ }^{53}$ Murphy, supra note 21, at 821.

${ }^{54} I d$. at $822-23$. At the same time, the president determined that Taliban detainees as a group were unlawful combatants and were not entitled to POW status. In so doing, the president prevented Taliban detainees from exercising any rights they may have had under Article 4 of the Third Geneva Convention to individualized determinations of their unlawful combatant status by a "competent tribunal" in the event that there was any "doubt" regarding their status. The Justice Department argued, however, that a presidential determination removed any doubts about their status and made individualized review by a tribunal unnecessary. Id.

${ }^{55} \mathrm{Id}$. at 822 (noting that Secretary of State Colin Powell had argued in a memorandum responding to Attorney General Gonzales that withholding POW status across the board would "reverse over a century of U.S. policy and practice in supporting the Geneva Conventions and undermine the protections of the law of war for our troops, both in this specific conflict and in general," and would have "a high cost in terms of negative international reaction").

${ }^{56}$ Irregular or militia forces enjoy the status of lawful combatants only if they have a responsible commander, wear distinctive and visible insignia, openly bear arms, and generally observe the laws and customs of war. Third Geneva Convention, supra note 8, Art. 4(A)(2). However, inflexible or rigid interpretations of rules such as those requiring lawful combatants to wear distinctive insignia are not consistent with the practice of the United States with respect to its own Special Forces. See W. Hays Parks, Special Forces' Wear of Non-Standard Uniforms, 4 CHI. J. INT'L L. 493 (2003).

${ }^{57}$ For example, the Clinton administration demanded that POW status be accorded to three American soldiers on a peacekeeping mission in Macedonia whom Serbian forces abducted along the border with Yugoslavia during the Kosovo conflict. See John H. Cushman Jr., Crisis in the Balkans: The Prisoners; New Focus Is on Status of the 3 as P.O.W.'s, N.Y. TIMES, Apr. 5, 1999, at A6.

${ }^{58}$ Oliver E. Williamson, The MeChanismS OF GovernanCe $48-49$ (1985); Kenneth A. Shepsle, Discretion, Institutions, and the Problem of Government Commitment, in SOCLAL THEORY FOR A CHANGING SOCIETY 245, 247, 254-57 (Pierre Bourdieu \& James S. Coleman eds., 1991). On the other hand, actions that promore an image of unpredictability serve to reduce a state's ability to make credible commitments. ROBERT O. KEOHANE, AFTER HEGEMONY: COOPERATION AND DISCORD IN THE WORLD POLITICAL ECONOMY 259 (1984). 
costly to exercise such discretionary power and reduces the attractiveness of breaching an agreement can serve such a signaling function. ${ }^{59}$ To the extent, however, that the MCA is perceived as unilaterally revising key obligations in the Geneva Conventions and providing the president with the discretion to issue further reinterpretations, it undermines the credible commitment of the United States to other states in the international community. ${ }^{60}$ And to the extent that the U.S. commitment is perceived as increasingly less credible, theory suggests that other countries are unlikely to maintain the stringency of their own commitments.

As for the future assertion of particular legal rights or obligations, the revisions of the Geneva Conventions officially sanctioned by the MCA may impede or estop the United States from taking legal positions that it has previously relied on to support its operations and protect its personnel from violations of the law of war. Furthermore, in adopting a statute that incorporates a flawed approach to the law of war to advance immediate U.S. objectives against terrorism, Congress may have inadvertently offered adversaries of the United States a legal model for future conflicts, with attendant negative consequences for U.S. operations and personnel.

In spite of the inherent risks for the United States that are associated with unilaterally reinterpreting or revising the Geneva Conventions, the MCA nonetheless does so. By redefining the concept of combatancy, for example, the MCA may have created a particularly destructive legal boomerang. Prior to the MCA's enactment, the U.S. government had sought carefully to maintain the distinction between combatants and noncombatants, not only for the purpose of preserving key law of war principles but also in a self-interested effort to prevent large numbers of U.S. civilians and contractors who support U.S. operations from becoming legitimate targets under the law of war. This effort appears to be particularly important as private contractors assume an increasingly significant role in supporting U.S. operations in countries such as Iraq. ${ }^{61}$ Current DoD regulations reflect considerable diligence in attempting to distinguish such contractors from combatants, in part by defining as "indirect" the role played by private contractors who provide communications support, transport munitions and other supplies,

59 Charles Lipson, Why Are Some International Agreements Informal? 45 INT'L ORG. 495, 508-11 (1991) (suggesting that the treaty-making process can serve such a signaling function).

${ }^{60}$ Because America confronts an enemy that is committed to terrorist acts and violations of the law of war, some may argue that a "differentiated" credible commitment by the United States is appropriate, i.e., one demonstrating to our Western allies a commitment to the law of war while rejecting sending a similar signal of commitment to Al Qaeda. Although a complete analysis of this position is beyond the scope of this brief Agora essay, such an approach raises at least two problems with respect to the MCA. First, as an official legislative act that is applicable to all unlawful combatants rather than a mere statement of policy in the war on terror, the MCA casts a long legal shadow over all U.S. commitments to the Geneva Conventions. Second, some suspected Qaeda terrorists are nationals of states that are close allies of the United States, making such a "differentiated" approach very difficult. See, e.g., Alan Cowell, Briton Wants Guantánamo Closed, N.Y. TIMES, May 11, 2006, at A24 (noting that after British attorney general Lord Goldsmith secured the release of nine Britons who were detained at Guantánamo Bay, he urged closure of that facility based on the failure of proposed U.S. military tribunals to offer "sufficient guarantees of fair trial in accordance with international standards").

${ }^{61}$ Griff Witte, New Law Could Subject Civilians to Military Trial; Provision Aimed at Contractors, but Some Fear It Will Sweep up Other Workers, WASH. POST, Jan. 15, 2007, at Al ("The Pentagon has estimated that there are 100,000 government contractors operating in Iraq, doing such jobs as serving meals, guarding convoys and interrogating prisoners."). Although then-defense secretary Rumsfeld defended the extensive use of private contractors in Iraq by saying it "frees up military personnel in combat zones," there has been considerable disagreement about what constitutes appropriate "nonmilitary" missions for these contractors. Peter Spiegel, U.S. Is Faulted for Using Private Military Workers; The Reliance on Security Firms to Interrogate and Transport Suspected Terrorists Has Created 'Rule-Free Zones, 'Says Amnesty International, L.A. TIMES, May 24, 2006, at A26; see also William Neikirk, Use of Contractors for Military Purposes Under Scrutiny, CHI. TRIB., May 9, 2004, at C16. 
maintain military equipment, and furnish various security and logistic services. ${ }^{62}$ Such concerns, along with interests in attending to command-and-control issues, are reflected in DoD regulations aimed at preventing contractors from becoming too closely associated with or involved in "major combat operations" that are "ongoing or imminent." 63

Rather than expecting accredited contractors who accompany and support U.S. forces to be treated as unlawful combatants in the event that they are captured in an armed conflict, DoD regulations presume they will be entitled to POW status under the Third Geneva Convention as "[p]ersons who accompany the armed forces without actually being members thereof." 64 Such status for civilians, however, remains contingent under the Third Geneva Convention on their not actively or directly participating in hostilities. Although legal risks may be associated with any civilian activity that closely supports combat operations, the fact that a civilian contributes in some general way to the war effort or is employed by or accompanies the armed forces does not turn him into a combatant. ${ }^{65}$ This statement has long been widely accepted as a formulation of the current rules, at least before Congress expanded the definition of combatancy in the MCA and risked confusing this extraordinarily key distinction upon which the United States has long relied. ${ }^{66}$

Congress's claim that the "new" war crimes in the MCA resembling domestic offenses merely codify existing war crimes seems unlikely to prevent the legal boomerang that springs from an action striking at the integrity of the law of war itself. While U.S. courts have yet to rule on Congress's claimed "codifications" in the MCA, the apparent inclusion of new war crimes will pose serious challenges to U.S. military commanders and their forces if they find themselves subject to the ex post facto application of new war crimes that originate in other countries' domestic legal systems. It also is not difficult to imagine that some states, if they became involved in a future armed conflict with the United States, might be tempted to make use of the legal approach fashioned by the U.S. Congress by creating new "war crimes" for captured U.S. personnel that reflect those states' very different political or religious beliefs. ${ }^{67}$

62 See Contractor Personnel Authorized to Accompany the U.S. Armed Forces, DoD Instruction 3020.41, sec. 6.1.1. (Oct. 3, 2005), available at $<$ http://www.dtic.mil/whs/directives/search.html $>$ (providing that contingency contractor personnel "may support contingency operations through the indirect participation in military operations, such as by providing communications support, transporting munitions and other supplies, performing maintenance functions for military equipment, providing security services . .. and providing logistic services such as billeting, messing, etc." (emphasis added)). Contractors are permitted to provide "security services" only if they are "for other than uniquely military functions." Id., sec. 6.3.5.

${ }^{63} I d$., sec. 6.3.5.2. This section provides:

Contracts shall be used cautiously in contingency operations where major combat operations are ongoing or imminent. In these situations, contract security services will not be authorized to guard U.S. or coalition military supply routes, military facilities, military personnel, or military property except as specifically authorized by the geographic Combatant Commander (non-delegable).

${ }^{64}$ Third Geneva Convention, supra note 8, Art. 4(A)(4); U.S. DEP'T OF THE ARMY, THE LAW OF LAND WARFARE, para. 61.A(4) (Field Manual 27-10, 1956); see also DoD Instruction 3020.41, supra note 62, sec. 6.1.1.

6s DINSTEIN, supra note 28 , at $28,42$.

${ }^{66}$ The MCA risks confusing some already uncertain aspects of this problem. Determining whether contractors and civilians who support a myriad of U.S. military activities are directly or actively engaged in hostilities has previously raised difficult questions with respect to some of the services that they provide. See generally Michael N. Schmitt, Humanitarian Law and Direct Participation in Hostilities by Private Contractors or Civilian Employees, 5 CHI. J. INT'L L. 511 (2005).

${ }^{67}$ An innovative attempt by North Korea in 1996 to create a new war crime to employ against a captured American helicopter pilot (based on his inadvertent violation of the Korean Armistice Agreement when his helicopter 
Other legal boomerangs in the MCA are presented by Congress's omission of some "vague" obligations under the Geneva Conventions. These omissions are particularly troubling if the United States seeks in the future to rely on rights corresponding to the absent obligations or if by its actions Congress encourages future adversaries also to omit law of war obligations on the same basis. Vagueness of Geneva Convention obligations has not previously stopped or limited protests by the United States regarding the mistreatment of captured U.S. military personnel. This principle was recently demonstrated in the Iraq conflict when U.S. officials vigorously objected to the broadcast of films that showed the questioning of captured American soldiers and other images of both dead and captured Americans. The basis for this protest was the requirement that "prisoners of war must at all times be protected, particularly against acts of violence or intimidation and against insults and public curiosity." 68 Invoking this provision, Bush administration officials strenuously objected to the "humiliating" treatment of captured Americans by Iraq and repeatedly demanded Iraq's compliance with its obligations under the Geneva Conventions. ${ }^{69}$ The United States has a long history of making such protests and invocations on behalf of captured Americans, regardless of the vagueness of legal phrases such as "insults" and "public curiosity," and accompanying terms such as "humiliation."

If in some future conflict the United States protests the mistreatment of its captured soldiers or otherwise demands compliance by a foreign state with Geneva Convention obligations, Congress through the MCA may not only have estopped some legal arguments upon which the nation has long relied, but also have given that foreign state a dangerous legal model to use in interpreting the scope and meaning of those obligations. By providing that "[n]o foreign or international source of law shall supply a basis for a rule of decision in the courts of the United States in interpreting prohibitions enumerated [as war crimes in the MCA],"70 Congress endorsed an approach to war crimes that could permit a future adversary to reject the same international legal norms and rules that the United States has supported and relied upon for over a century. The congressionally sanctioned rejection of all "non-U.S. sources" of law for determining war crimes applicable to U.S. personnel thus will not be a useful model if it helps to inspire, for example, the rejection of all "non-North Korean law sources" in some future armed conflict with North Korea.

By conflating war crimes that are generally understood to arise in the context of conflicts of an international character with the narrower set of rules that are generally understood to apply to noninternational conflicts, the MCA has also created a hybrid set of offenses that challenge the current framework of the law of war. While not all the consequences of this action are clear, applying rules that are generally reserved for combatants in international armed conflicts to suspected Qaeda terrorists may in the long term undermine U.S. arguments against extending

crashed in North Korea) demonstrates the hazards of U.S. encouragement of such unilateral legal innovations. See Scott R. Morris, America's Most Recent Prisoner of War: The Warrant Officer Bobby Hall Incident, ARMY LAW., Sept. 1996, at 3 (North Korea later declined to pursue these charges).

${ }^{68}$ Third Geneva Convention, supra note 8, Art. 13.

${ }^{69}$ Adam Liptak, A Nation at War: Geneva Conventions; Public Opinion Effort Leans on Rules of War, N.Y. TIMES, Mar. 26, 2003, at B1 1 (noting Pentagon spokeswoman Victoria Clarke's criticism of the Iraqi actions and quoting her as saying, "It is a blatant violation of the Geneva Convention to humiliate or abuse prisoners of war or to harm them in any way.").

${ }^{70}$ MCA sec. 6(a)(2), 18 U.S.C. $\$ 2441$ note. On the domestic level, whether Congress has the power to dictate these terms to U.S. courts is likely to generate considerable debate, along with provisions that imply deference by U.S. courts to the president's binding interpretations of treaty obligations. Carlos Manuel Vázquez, The Military Commissions Act, the Geneva Conventions, and the Courts, 101 AJIL 73, 77-79 (2007) (in this Agora). 
a variety of protections and other rules associated with international armed conflicts to the conflict with Al Qaeda. ${ }^{71}$ It may also contribute to the "gradual erosion of the concepts of resistance, freedom fighter, guerrilla and terrorist movements" that the United States has long opposed. ${ }^{72}$ In essence, the continuing attempt to apply a model based on war instead of crime to suspected Qaeda terrorists risks cloaking these individuals with legal trappings that increasingly resemble those of warriors instead of criminals.

While some commentators may welcome the extension of POW status to alleged Qaeda terrorists so as to permit their detention for the uncertain duration of the conflict with terrorism, ${ }^{73}$ such an approach certainly is not consistent with the systematic criminal inquiries and related intense interrogation practices that are envisioned by the Bush administration for these detainees. ${ }^{74}$ In addition, an approach that equates a lawful combatant detained as a POW with a "violent mental patient subject to civil confinement" ${ }^{\prime 5}$ does not serve either the practical functions or the humanitarian purposes of the law of war and the Geneva Conventions. It is also not easily reconciled with many of the privileges to which POWs are entitled or the treatment that the United States will demand in future conflicts for captured lawful combatants who are Americans.

\section{POLITICAL BOOMERANGS: BEYOND GUANTÁNAMO BAY}

Political boomerangs are likely to be caused by the MCA's negative impact on U.S. efforts to combat terrorism that require international cooperation related to criminal matters, the use of critical foreign facilities, and foreign state approval of key aspects of U.S. counterterror operations. To be successful, finding, tracking, fighting, capturing, detaining, interrogating, transferring, extraditing, and trying terrorists often require an extraordinary level of international cooperation. At one time, many U.S.-sponsored activities in this area enjoyed considerable international support and could be discreetly undertaken on foreign soil with little scrutiny. This situation has changed dramatically as a result of highly publicized reports of the mistreatment of detainees in U.S. custody, the detention of suspected terrorists in secret prisons, and the seizure and subsequent rendition of persons to states where they may be subject to torture or harsh interrogation techniques. The active support or quiet complicity of several European states in these actions continues to be investigated and criticized by the European Parliament,

\footnotetext{
${ }^{71}$ Actions characterizing the conflict with Al Qaeda as an international armed conflict might logically also lead to the undesirable conclusion that U.S. military installations are legitimate targets for Qaeda attacks. See Joan Fitzpatrick, Jurisdiction of Military Commissions and the Ambiguous War on Terrorism, 96 AJIL 345, 348 (2002).

72 INGRID DETTER, THE LAW OF WAR 144 (2d ed. 2000).

${ }^{73}$ See Jack Goldsmith \& Eric A. Posner, A Better Way on Detainees, WASH. POST, Aug. 4, 2006, at A17.

${ }^{74}$ The Third Geneva Convention does not prohibit interrogation of POWs, but it does provide that a POW "is bound to give only his surname, first names and rank, date of birth, and army, regimental, personal or serial number," and that "[n]o physical or mental torture, nor any other form of coercion, may be inflicted on prisoners of war to secure from them information of any kind whatever. Prisoners of war who refuse to answer may not be threatened, insulted, or exposed to unpleasant or disadvantageous treatment of any kind." Third Geneva Convention, supra note 8, Art. 17. Although the Convention does not envision that POWs are to be subjected to intensive interrogations and they may also be obligated by their own military commanders not to cooperate in providing useful information to their captors, the MCA makes "perjury," "false testimony," and "obstruction of justice" punishable offenses. See supra note 33.

${ }^{75}$ Goldsmith \& Posner, supra note 73.
} 
the Council of Europe, and individual European parliaments, ${ }^{76}$ and may lead to criminal charges against U.S. intelligence officers and responsible government officials in some European states. ${ }^{77}$ These developments have generally served to undermine public support in European and other states for cooperative activities with the United States concerning detainees, as evidenced by the recent remarks of the legal adviser of the U.S. Department of State who conceded that trying to explain U.S. detention policies to foreign audiences was "clearly an uphill battle."78

It is into this highly charged and mistrustful environment that the military commissions sanctioned by the MCA are being introduced, against a backdrop of intense skepticism regarding the fairness and independence of military courts generally. ${ }^{79}$ This skepticism prompted some countries, immediately after President Bush authorized the use of military commissions, to threaten to refuse to extradite suspected terrorists to the United States without assurances that they would be tried in civilian courts. ${ }^{80}$ The attempt by Congress in the MCA to reinterpret or revise Geneva Convention obligations and law of war principles seems more likely to increase, rather than to reduce, such skepticism on the part of foreign governments.

The United States, of course, will continue to argue that even though its military commissions do not afford unlawful combatants all the same protections that its own military personnel enjoy in regular courts-martial, the commissions' proceedings are fundamentally fair and do not deserve the nefarious reputation associated with military trials elsewhere. Unfortunately, MCA provisions stripping suspected terrorists in military proceedings of habeas corpus rights leading to their prolonged detention without charges or trial ${ }^{81}$ are reminiscent of the practices of other countries in states of emergency that are often associated with serious violations of human rights, including torture and cruel, inhuman, and degrading treatment or punishment. $^{82}$

The principal place of detention and interrogation of suspected Qaeda terrorists, the U.S. Naval Base Guantánamo Bay (Guantánamo), has been the primary focus of legal attention because of the Bush administration's unsuccessful argument that its location on foreign soil denied detainees access to U.S. courts. Although Guantánamo remains under Cuban sovereignty, the Supreme Court in Rasulv. Bush recognized that United States authorities effectively

${ }^{76}$ Brian Knowlton, Report Rejects European Denial of C.I.A. Prisons, N.Y. TIMES, Nov. 29, 2006, at A15; Mark Landler \& Souad Mekhennet, Freed German Detainee Questions His Country's Role, N.Y. TIMES, Nov. 4, 2006, at A8; Craig Whitlock, European Report Details Flights by CLA Aircraft; Polish, Romanian Facilities Cited, WASH. POST, Nov. 29, 2006, at A14.

77 Ian Fisher \& Elisabetta Povoledo, Italy's Top Spy Is Expected to Be Indicted in Abduction Case, N.Y. TIMES, Oct. 24, 2006, at A3; Ian Fisher \& Elisabetta Povoledo, Italy Seeks Indictments of C.I.A. Operatives in Egyptian's Abduction, N.Y. TIMES, Dec. 6, 2006, at A12.

${ }^{78}$ Crawley, supra note 43.

${ }^{79}$ Harold Hongju Koh, The Case Against Military Commissions, 96 AJIL 337 (2002).

${ }^{80}$ Sean D. Murphy, Contemporary Practice of the United States, 96 AJIL 237, 255 (2002).

${ }^{81}$ Section $7(\mathrm{a})$ of the MCA amends 28 U.S.C. $\$ 2241$ by adding the following subsection:

(e)(1) No court, justice, or judge shall have jurisdiction to hear or consider an application for a writ of habeas corpus filed by or on behalf of an alien detained by the United States who has been determined by the United States to have been properly detained as an enemy combatant or is awaiting such determination.

The MCA places no limit on the length of time a detainee may be required to wait for the initial determination of status or subsequent trial and instead makes the U.C.M.J. requirement for a speedy trial inapplicable to military commissions. 10 U.S.C. $\$ 948 \mathrm{~b}(\mathrm{~d})(\mathrm{l})(\mathrm{A})$.

${ }^{82}$ Fitzpatrick, supra note 71 , at 350 . 
exercise control over the territory for purposes of habeas corpus rights. ${ }^{83}$ An equally important, but less recognized, aspect of Guantánamo is its insulated legal status compared to other overseas U.S. military facilities.

The conditions at Guantánamo are characterized by the complete independence of U.S. activities there from the jurisdiction or ultimate control of the host state. Even long-established U.S. bases in Europe, which provide key airfields, ports, and other facilities that support many U.S. counterterror operations and that enjoy the benefit of numerous post-World War II concessions by the host states, are not legal zones in which all U.S. activities occurring there are exempt from the host state's jurisdiction, control, and ultimate sovereignty. ${ }^{84}$ To support military and intelligence operations and other defense-related activities around the world, the United States has entered into a wide range of different types of international agreements with foreign states. Only in the most exceptional cases like Guantánamo, however, have sovereign states relinquished complete jurisdiction or control over their respective territories as regards American operations that might take place there.

Depending on the international agreement that governs the facility, host states exercise varying degrees of jurisdiction and control over activities and persons there. ${ }^{85}$ Although many of these agreements address the status of U.S. military and civilian personnel in that state by significantly restricting local criminal and civil jurisdiction over them and by providing various rights and privileges, rarely do such agreements exempt all U.S. activities there from the ultimate sovereignty of that state. The desire of states to reject any model similar to the one represented by Guantánamo and to ensure continued sovereignty over facilities where U.S. military forces are present is so great that even the term "U.S. base" is rarely found in contemporary agreements. Instead, host governments are more likely to grant only certain limited rights of access to, and usage of, designated "locations" or "facilities." 86

\footnotetext{
${ }^{83}$ Rasul v. Bush, 542 U.S. 466, 484 (2004). The Court noted that by the express terms of a 1903 lease agreement, "the United States exercises 'complete jurisdiction and control' over the Guantanamo Bay Naval Base, and may continue to exercise such control permanently if it so chooses." Id. at 480; see also Kal Raustiala, The Geography of Justice, 73 FORDHAM L. REV. 2501 (2005).

${ }^{84} \mathrm{~A}$ notable example of a European state exercising its sovereignty over a U.S. military base and related efforts there to bring terrorists to justice occurred in 1985 when U.S. fighters intercepted an Egyptian airliner and forced it to land at a U.S. naval air station located at Sigonella, Italy. The plane was carrying Abu Abbas and other members of the Palestine Liberation Front who were alleged to have hijacked the cruise liner Achille Lauro and murdered an American passenger. Although U.S. military personnel attempted to arrest the passengers on the plane, Italian police intervened and made their own arrests, Abu Abbas went free, and Italy filed protests with the United States claiming that its airspace had been violated by the U.S. fighters. See Robert J. Beck \& Anthony Clark Arend, "Don't Tread on Us": International Law and Forcible State Responses to Terrorism, 12 WIS. INT'L L.J. 153, 176 (1994).

${ }^{85}$ International agreements governing U.S. military activities in foreign states may be quite detailed and elaborate and, unlike informal arrangements, such agreements are much more likely to be subject to procedures that involve different agencies or departments of each government, as well as their respective legislative branches. This is largely true even if the agreements are classified, as reflected in U.S. government regulations that require classified agreements to conform to various requirements applicable to other agreements and to be submitted after their conclusion through appropriate channels to designated committees of the U.S. Congress. See Coordination, Reporting and Publication of International Agreements, 22 C.F.R. 181.7(b), (c), (d) (2006). To the extent that any U.S. activities related to detainees have taken place in European states based on secret informal arrangements, the resulting public outrage and governmental investigations following disclosures of such alleged activities would seem likely to make such an informal approach far more difficult in the future.

${ }^{86}$ Facilities in foreign states that are used by U.S. forces for operations against both illicit drug trafficking and terrorism provide contemporary examples of international agreements in which states provide only specific types of access, usage, and other rights. See, e.g., Agreement on Access to and Use of Facilities in the Republic of Djibouti,
} 
Under these circumstances, the ability of U.S. military authorities to engage in a wide range of activities at overseas facilities related to the detention, interrogation, trial, or transfer of accused terrorists without any involvement by local authorities may face serious, long-term difficulties. Differing views by host or supporting governments regarding U.S. compliance with local and international legal obligations thus may not be easily ignored. To the extent that the MCA raises questions about U.S. obligations under the Geneva Conventions, the law of war, and related human rights treaties with respect to the treatment and military trial of detainees, new complications for U.S. counterterror operations at foreign facilities will present themselves. The growing protests of European officials over clandestine activities related to the detention and transfer of suspected terrorists that are alleged to have occurred on their territories also suggest that informal secret operations may become more difficult to conduct and that U.S. actions in this area are more likely to be publicly entangled with the competing legal requirements of some foreign jurisdictions. Even states that lack a strong human rights record may have an interest in asserting their control and sovereignty over U.S. military activities on their soil and seek to avoid complications that result from the use of their territories for widely criticized types of detainee treatment. Finally, no matter what foreign territory in which they occur, operations involving detainees are not immune from legal problems and protests generated by the perceived mistreatment of nationals of the foreign states that are supporting those operations.

Another complication for U.S. military forces caused by the adverse reactions of states to MCA-sanctioned activities is their impact on a wide variety of cooperative military activities that support counterterror operations but do not necessarily involve U.S. facilities overseas. The projection of military power to potentially every part of the globe so as to conduct these operations has many implications: U.S. naval vessels require critical transit rights and access to ports; U.S. military aircraft require overflight and landing rights; and ground, air, and naval forces depend on an international network of logistic support activities, in many cases requiring fuel, ammunition, and other supplies to be pre-positioned in foreign countries. These and other requirements make most major U.S. military operations dependent on significant levels of foreign state authorization and international cooperation. For this reason, legal disputes with foreign states regarding the status, treatment, detention, trial, and transfer of detainees have the potential dramatically to undercut various important U.S. antiterror operations.

\section{CONCLUSION}

If the struggle against terrorism involves more than just military engagements and is also a war of ideas, American support for law and international legal principles appears to constitute a key part of that war. However, the United States has additional incentives for eschewing efforts like those in the MCA that minimize the role of international law and reinterpret or revise obligations under the Geneva Conventions and the law of war with a view to combating

U.S.-Djib., Feb. 19, 2003, Temp. State Dep't No. 03-29, 2003 U.S.T. LEXIS 8; Agreement Concerning the Status of United States Military and Civilian Personnel of the United States Department of Defense Who May Be Present in Kyrgyzstan in Connection with Cooperative Efforts in Response to Terrorism, Humanitarian Assistance and Other Agreed Activities, U.S.-Kyrg., Dec. 5, 2001, Temp. State Dep't No. 02-84, 2001 U.S.T. LEXIS 95; Interim Agreement Concerning the Use of Facilities in Ecuador to Increase Aerial Detection and Control of Illegal Narcotics Trafficking Operations, U.S.-Ecuador, Mar. 31, 1999, Temp. State Dep't No. 99-55, 1999 U.S.T. LEXIS 81. 
terrorism. To find them, it need look no farther than its own interests in obtaining essential international cooperation for its current counterterror operations and in being able to rely in future conflicts on the existing law of war regime, rather than in handing future adversaries an ill-conceived legal model to use against it in those conflicts. 